\title{
Potensi Vaksin Antibodi Anti-PfRH5 Berbasis Nanopartikel Liposom sebagai Modalitas Preventif Mutakhir pada Plasmodium falciparum Malaria
}

\author{
Agung Bagus S. Satyarsa, Feliani Sanjaya, Ni Made Gitari \\ Program Studi Pendidikan Dokter, Fakultas Kedokteran, Universitas Udayana, Denpasar, Bali
}

\begin{abstract}
Abstrak
Plasmodium falciparum malaria dalah salah satu penyakit infeksi yang disebabkan oleh parasit protozoa Plasmodium falciparum dengan morbiditas dan mortalitas terbesar kasus malaria pada manusia. Upaya pencegahan dan penanganan Plasmodium falciparum malaria saat ini masih mendapat hambatan yaitu adanya resistensi terhadap insektisida dan obat anti-malaria. Untuk itu, perlu adanya metode pencegahan parasit yang bersifat lebih spesifik. Tujuan penulisan ini adalah untuk mengetahui potensi vaksin antibodi anti-PfRH5 berbasis nanopartikel liposom sebagai modalitas preventif mutakhir pada Plasmodium falciparum malaria. Metode yang digunakan dalam penulisan artikel review ini yaitu dengan penelusuran pusaka. Pencarian menghasilkan 60 jurnal yang ditelaah dan setelah diskrining jumlah jurnal yang digunakan yaitu 48 jurnal yang sesuai dengan topik bahasan. Pada siklus hidup Plasmodium falciparum terjadi fase invasi terhadap eritrosit. Plasmodium falciparum Reticulocyte-binding Protein Homologue 5 (PfRH5) dan basigin (BSG) dari eritrosit adalah pasangan ligan-reseptor esensial dalam invasi eritrosit. Tambahan nanopartikel liposom sangat penting untuk melindungi komponen vaksin antibodi antiPfRH5 agar tidak mudah mengalami degradasi yang membantu untuk meningkatkan efikasi kerja vaksin dalam menginhibisi proses invasi oleh merozoit. Karena berperan sebagai target yang penting dalam menginhibisi invasi merozoit, potensi PfRH5 sebagai vaksin malaria sangat signifikan dan spesifik. Potensi PfRH5 juga didukung dengan munculnya respon imun alami yang dapat menghambat pertumbuhan parasit. Respon imun tersebut melibatkan IgG spesifik terhadap PfRH5 yang dapat memberikan efek protektif dengan menghambat terjadinya ikatan antara PfRH5-BSG sehingga proses invasi tidak terjadi. Vaksin PfRH5 berbasis liposom yang spesifik pada merozoit merupakan modalitas pencegahan potensial dalam perkembangan vaksin Plasmodium falciparum malaria. Penelitian lebih lanjut diperlukan untuk mengetahui efikasi dan induksi antibodi pada tubuh oleh vaksin PfRH5.
\end{abstract}

Kata kunci: Plasmodium falciparum malaria, nanopartikel liposom, vaksin PfRH5

\section{Potential of Anti-PfRH5 Antibody Vaccine Based on Liposome Nanoparticles as the Latest Preventive Modalities in Plasmodium falciparum Malaria}

\begin{abstract}
Plasmodium falciparum malaria is an infectious disease caused by the protozoa Plasmodium falciparum, estimated to have the greatest morbidity and mortality of all cases in humans. In addition, prevention and treatment efforts are currently being challenged by resistance to insecticides and anti-malaria drugs. This instigates the need for a more specific prevention method. This article, therefore, aims to determine the potential of anti-PfRH5 antibody vaccines, based on liposome nanoparticles, as the final preventive modality in Plasmodium falciparum malaria. The method used in this review involved searching study literature. The search resulted in 60 journals, and a total of 48 were obtained after screening according to the topic of discussion, and thus adopted as references to this work. Furthermore Plasmodium falciparum life cycle is characterized by an invasion phase of erythrocytes, where the Reticulocyte-binding Protein Homologue 5 (PfRH5) and basigin (BSG) serve as essential ligand-receptor pairs. The addition of liposome nanoparticles is vital to protect the anti-PfRH5 antibody vaccine component, and prevent easy degradation, thus improving the vaccine efficacy in the inhibiting the merozoites invasion process. This potential target as a malaria vaccine is very significant and specific, and is supported by the emergence of natural immune responses capable of deterring parasite growth. The immune response involves the action of specific IgG, estimated to provide a protective effect by inhibiting the occurrence of a PfRH5-BSG bond, therefore preventing the invasion process occurrence. Therefore, liposome-based PfRH5 vaccine specific to merozoites is a prospective preventive modality in the development of a Plasmodium falciparum malaria vaccine, although further research is needed to determine the efficacy and possible induction of antibodies in the body.
\end{abstract}

Keywords: Plasmodium falciparum malaria, liposome nanoparticle, PfRH5 vaccine

Korespondensi: dr. Agung Bagus S. Satyarsa, S.Ked., Program Studi Pendidikan Dokter, Fakultas Kedokteran, Universitas Udayana, Denpasar, Bali 80234, Indonesia, email: abssatyarsa@student.unud.ac.id Naskah diterima: 19 September 2019, Diterima untuk diterbitkan: 20 Februari 2020, Diterbitkan: 29 Juni 2020 


\section{Pendahuluan}

Plasmodium falciparum (P. falciparum) malaria disebabkan oleh protozoa Plasmodium falciparum dengan diperantarai oleh nyamuk Anopheles betina. ${ }^{1}$ P. falciparum malaria merupakan jenis malaria dengan prevalensi dan mortalitas tertinggi di dunia. ${ }^{2}$ Hampir separuh dari populasi penduduk dunia saat ini, yaitu sekitar 3,2 miliar penduduk, dalam kondisi berisiko terinfeksi malaria. Setiap tahunnya, diperkirakan terdapat sekitar 1-3 juta kematian akibat malaria secara global terutama pada anak dengan usia $<5$ tahun dan ibu hamil. ${ }^{3}$ Pada tahun 2015, diperkirakan terdapat total 214 juta kasus malaria dengan angka mortalitas sebanyak 438 ribu jiwa di seluruh dunia. ${ }^{2}$ Penyakit malaria masih dapat dijumpai di seluruh provinsi di Indonesia, terutama di wilayah timur Indonesia yang merupakan wilayah endemik malaria. Data Riskesdas tahun 2013 menyatakan prevalensi malaria di Indonesia adalah $6,0 \%$ dengan infeksi $P$. falciparum merupakan jenis yang dominan jika dibandingkan spesies lainnya. Lima provinsi dengan insiden dan prevalensi tertinggi adalah Papua, Nusa Tenggara Timur, Papua Barat, Sulawesi Tengah dan Maluku. ${ }^{4}$

Selain memiliki tingkat mortalitas dan prevalensi yang cukup tinggi, penyakit malaria falciparum juga memiliki tingkat morbiditas dan progresivitas yang tinggi. Gejala-gejala awal dari $P$. falciparum malaria bersifat nonspesifik dan menyerupai gejala penyakit viral sistemik minor seperti sakit kepala, keletihan, rasa sakit pada regio abdomen, nyeri sendi dan otot, juga bisa disertai oleh demam, menggigil, berkeringat, kehilangan nafsu makan, serta batuk. Ketika gejalagejala awal ini muncul, tidak ditemukan tanda-tanda kegagalan fungsi organ tubuh dan dapat sembuh jika diberikan pengobatan yang tepat. Namun apabila pengobatan yang diberikan tidak sesuai atau bahkan pengidap tidak mendapat pengobatan apapun, maka jumlah $P$. falciparum dalam tubuh akan terus meningkat dan kemudian berpotensi memperparah penyakit malaria hingga dapat bersifat fatal bahkan letal. Progresivitas dari gejala awal menuju gejala malaria yang lebih berat hanya membutuhkan durasi beberapa hari, atau bahkan dalam hitungan jam. Penyakit malaria berat menunjukkan salah satu atau lebih dari manifestasi klinis berikut ini yaitu koma (cerebral malaria), asidosis metabolik, anemia parah, hipoglikemia, gagal ginjal akut, atau edema paru akut. Efek patologis dan manifestasi klinis yang muncul berpotensi lebih parah pada ibu hamil, bayi, dan balita dengan malaria., ${ }^{1,5}$

Upaya preventif terhadap transmisi malaria direkomendasikan oleh World Health Organization (WHO) dalam dua bentuk metode kontrol vektor yaitu insecticide-treated mosquito nets (ITNs) dan indoor residual spraying (IRS). ${ }^{2}$ Kedua metode kontrol vektor tersebut juga dilakukan di Indonesia sesuai program elimininasi malaria. ${ }^{6}$ Namun dalam beberapa tahun terakhir, resistensi vektor terhadap insektisida yang digunakan dalam kedua metode tersebut muncul di beberapa negara. ${ }^{2}$ Selain itu, tindakan kuratif pada malaria bertujuan untuk menghilangkan parasit $P$. falciparum dalam darah supaya penyakit tidak menyebabkan komplikasi maupun infeksi kronis seperti anemia terkait malaria.

Kebijakan monoterapi yaitu dengan penggunaan obat golongan aminoquinolin dan antifolat. ${ }^{1,7}$ Adanya mutasi di salah satu asam amino, K76T, pada gen $P$. falciparum chloroquine resistance transporter (pfcrt) diketahui menjadi penyebab dari resistensi obat anti-malaria sebelumnya. ${ }^{7,8}$ Saat ini, artemisinin-based combination therapy (ACT) merupakan lini pertama pengobatan malaria di dunia, termasuk di Indonesia. ${ }^{9,10}$ Namun resistensi terhadap obat anti-malaria masih menjadi penghadang utama dalam penanganan malaria. ${ }^{11}$ Pada tahun 2008, 
dilaporkan adanya $P$. falciparum resisten terhadap derivat artemisinin. ${ }^{1,9}$ Resistensi tersebut lalu menimbulkan kesulitan dalam pengobatan $P$. falciparum malaria. ${ }^{1}$ Hal ini tentunya dapat menghambat baik pencegahan dan penanganan malaria sehingga dibutuhkan modalitas pencegahan lain yang lebih efektif seperti vaksin.

Sebuah vaksin $P$. falciparum pre-eritrosit dengan target sporozoit, 'RTS,S' baru-baru ini menjalani fase ketiga dari clinical trial terhadap anak-anak di Afrika. Dari hasil yang diperoleh, vaksin tersebut memiliki efikasi parsial hanya sebesar 29-36\%. Vaksin dengan target merozoit memiliki potensi yang cukup menjanjikan. ${ }^{12,13}$ Merozoit $P$. falciparum diketahui memiliki beberapa jenis protein yang berperan penting dalam proses invasi eritrosit, salah satunya adalah reticulocytebinding protein homologue $(\mathrm{RH}) .{ }^{14}$ Salah satu jenis dari RH protein $P$. falciparum adalah PfRH5. Plasmodium falciparum reticulocyte-binding protein homologue 5 (PfRH5) adalah protein esensial dalam invasi eritrosit pada semua strain P. falciparum. ${ }^{14,15}$ Antigen PfRH5 juga diketahui bersifat spesifik terhadap reaksi imun karena memiliki polimorfisme yang terbatas. Antibodi yang ditargetkan pada PfRH5 dapat secara efektif menghalangi invasi $P$. falciparum in vitro. ${ }^{16-18}$ PfRH5 juga dapat merangsang antibodi penetral melebihi potensi strain. ${ }^{17,19}$

Penggunaan liposom sebagai penghantar obat sudah sejak tahun 1960 dengan ukuran sekitar 150-200 nm. Liposom merupakan sebuah sistem pengiriman yang penting untuk vaksin disebabkan oleh fleksibilitasnya yang tinggi, sehingga akan cocok untuk berbagai jenis antigen. ${ }^{20}$ Vaksin liposomal memiliki keunggulan antara lain aman, biodegradable, kemungkinan penggabungan antigen yang berbeda (protein, peptida, karbohidrat, asam nukleat dan hapten) sehingga meningkatkan bioavaibilitas, serta dapat menyesuaikan untuk menargetkan pada sel tertentu dengan penggabungan ligan..$^{21,22}$ Berdasarkan data dan fakta di atas, vaksin antibodi anti-PfRH5 berbasis nanopartikel liposomal berpotensi menjadi vaksin sebagai modalitas preventif sebagai upaya penatalaksanaan penyakit P. falciparum malaria.

\section{Metode}

Metode yang digunakan dalam penulisan artikel tinjauan pustaka ini adalah dengan penelusuran pustaka yaitu artikel mengenai P. falciparum malaria, PfRH5, Plasmodium falciparum, vaksin malaria dan nanopartikel liposom dengan menggunakan situs pencari yakni Google Scholar dan Pubmed. Selain itu, pencarian artikel acuan juga dilakukan pada database jurnal terpercaya seperti NCBI, Sciencedirect, Proquest dan beberapa situs lainnya. Kata kunci yang digunakan antara lain "PfRH5 dan Plasmodium falciparum" serta "Kandidat vaksin dan nanopartikel liposom". Pustaka diinklusi dan dieksklusi dengan berdasarkan kriteria: artikel ilmiah yang menggunakan bahasa Inggris, bahasa Indonesia, dan memiliki abstrak dalam artikel ilmiah tersebut. Pencarian awal menghasilkan 60 artikel, dan setelah dilakukan skrining dan telaah, diperoleh bahwa jumlah artikel yang digunakan sebagai refrensi karya ini yaitu 13 artikel utama dan 35 artikel pendukung.

\section{Hasil}

Berdasarkan hasil dari beberapa penelitian yang dilakukan sebelumnya baik secara in vivo maupun in vitro, terdapat peningkatan sistem imunitas yang ditandai dari efektivitas antibodi anti-PfRH5. Adapun hasil telaah pustaka yang diperoleh dari artikel diuraikan pada Tabel 1.

\section{Pembahasan}

Terdapat dua siklus hidup dari Plasmodium 
Tabel 1 Peran Anti-PfRH5 sebagai Inovasi Vaksin terhadap P. Falciparum Malaria

\begin{tabular}{|c|c|c|c|c|}
\hline Peneliti & Metode & Target & Sampel & Hasil \\
\hline Bustamante et al. ${ }^{16}$ & $\begin{array}{l}\text { Eksperimental } \\
\text { Antibodi, in vitro }\end{array}$ & Eritrosit & $\begin{array}{l}\text { Parasit } P \text {. falciparum } \\
\text { strain 37D }\end{array}$ & $\begin{array}{l}\text { Antibodi dapat } \\
\text { menginhibisi invasi } 9 \\
\text { strain } P \text {. falciparum }\end{array}$ \\
\hline Reddy et $a l .{ }^{18}$ & $\begin{array}{l}\text { Eksperimental } \\
\text { Antibodi, in vitro } \\
\text { dan in vivo }\end{array}$ & Eritrosit & $\begin{array}{l}\text { Parasit } P \text {. falciparum } \\
\text { strain 37D } \\
\& \text { mencit }\end{array}$ & $\begin{array}{l}\text { Rekombinan antibodi } \\
\text { untuk menghambat invasi } \\
\text { P. falciparum }\end{array}$ \\
\hline Chen et al. ${ }^{34}$ & $\begin{array}{l}\text { Eksperimental } \\
\text { in vivo }\end{array}$ & $\begin{array}{l}\text { Eritrosit dan } \\
\text { merozoit }\end{array}$ & $\begin{array}{l}\text { Parasit } P \text {. falciparum } \\
\text { aseksual, } \\
\text { mencit \& kelinci }\end{array}$ & $\begin{array}{l}\text { Antibodi dari anti-PfRH5 } \\
\text { memblok regenerasi dari } \\
\text { merozoid } P \text {. falciparum }\end{array}$ \\
\hline William et al. ${ }^{39}$ & $\begin{array}{l}\text { Eksperimental } \\
\text { in vivo }\end{array}$ & Merozoit & $\begin{array}{l}\text { Parasit } P \text {. falciparum } \\
(37 \mathrm{D}+\mathrm{FVO}) \\
\text { PfRH5 } \\
\text { \& kelinci }\end{array}$ & $\begin{array}{l}\text { Antibodi dari } \\
\text { pengmbangan } \\
\text { PfRH5 sangat efektif } \\
\text { menghambat isolat parasit } \\
P \text {. falciparum }\end{array}$ \\
\hline Douglas et al. ${ }^{44-46}$ & $\begin{array}{l}\text { Eksperimental } \\
\text { in vivo }\end{array}$ & $\begin{array}{l}\text { Pengembangan } \\
\text { vaksin berbasis } \\
\text { PfRH5 }\end{array}$ & $\begin{array}{l}\text { Parasit } P \text {. falciparum } \\
\text { strain 37D \& } \\
\text { Aotus monkeys }\end{array}$ & $\begin{array}{l}\text { Proteksi dari antibodi } \\
\text { anti-PfRH5 terhadap } \\
\text { parasit } P \text {. falciparum serta } \\
\text { aktivitas efek parasite- } \\
\text { neutralizing secara in } \\
\text { vitro }\end{array}$ \\
\hline Rodriguez et al. ${ }^{47}$ & $\begin{array}{l}\text { Eksperimental } \\
\text { in vitro, } \\
\text { immunology assay }\end{array}$ & $\begin{array}{l}\text { Invasi eritrosit, } \\
\text { reseptor, } \\
\text { antibody } \operatorname{IgG}\end{array}$ & $\begin{array}{l}\text { Parasit P. falciparum } \\
\text { PfRH5 }\end{array}$ & $\begin{array}{l}\text { Ekspresi } 63 \mathrm{kDa} \text { protein, } \\
\text { anti-RH5 tidak bisa } \\
\text { menghambat invasi } \\
\text { merozoit }\end{array}$ \\
\hline
\end{tabular}

yaitu, fase seksual terjadi di nyamuk betina dan fase aseksual terjadi di hospes. ${ }^{23,24}$ Nyamuk Anopheles betina melalui gigitan mentransmisikan malaria menuju tubuh manusia. ${ }^{1}$ Selain menginfeksi manusia baik secara alami melalui gigitan vektor, infeksi malaria juga dapat terjadi melalui induksi seperti jalur transfusi darah, injeksi, dan bisa juga karena faktor genetik. ${ }^{25,26}$ Infeksi bermula ketika vektor nyamuk yang mengandung Plasmodium di dalam tubuh menusuk tubuh hospes, pada saat yang bersamaan, sporozoit Plasmodium akan masuk ke sirkulasi darah pada tubuh hospes. Masa sporozoit dalam sirkulasi darah ini berkisar antara setengah jam hingga satu jam, selanjutnya sporozoit akan menginvasi ke dalam sel hepatosit. Inti sel dari sporozoit ini akan bereplikasi secara kontinu dan berkembang membentuk merozoit. ${ }^{24,25,27}$ Tahap ini merupakan tahap skizogoni praeritrosit. Panjang tidaknya tahap ini bergantung pada jenis Plasmodium yang menginfeksi hospes. Setelah tahap pra -eritrosit berakhir, skizon akan pecah dan merozoit akan keluar, kemudian memasuki tahapan siklus blood-stage. Pada tahap ini, merozoit dilepaskan ke aliran darah akan segera menginvasi eritrosit. ${ }^{23-25}$ Di dalam eritrosit, merozoit dari $P$. falciparum akan berkembang ke tahapan membentuk tropozoit, skizon, dan selanjutnya skizon tersebut pecah mengeluarkan merozoit-merozoit baru yang akan menginfeksi sel eritrosit baru. Proses ini terus berlanjut dalam fase aseksual di dalam tubuh manusia. Replikasi dari tahapan bloodstage ini membutuhkan waktu sekitar 48 jam tiap siklusnya. ${ }^{24,28}$

Ditinjau dari segi molekuler, tahap invasi eritrosit oleh merozoit dibagi menjadi tiga fase yang berbeda yaitu prainvasi, invasi aktif, dan 
echinocytosis. Pada fase prainvasi, merozoit mulai berinteraksi dengan eritrosit dalam afinitas rendah yang diiringi oleh deformasi bentuk membran pada eritrosit target. ${ }^{29,30}$ Terdapat dua jenis protein ligan esensial yang memengaruhi tahap pra invasi menuju tahap invasi dengan cara menyediakan jalur untuk invasi. Dua ligan tersebut yakni $P$. falciparum reticulocyte-binding protein homologue (PfRhs) dan erythrocyte-binding like protein (EBLs). ${ }^{30-33}$ Fase pra invasi ini terjadi selama sekitar 10 detik. ${ }^{30}$ Setelah itu, merozoit akan mengeluarkan ligan dari organel apikalnya (microneme dan rhoptry) untuk menginvasi eritrosit (Gambar 1). ${ }^{29,30}$ Fase invasi merozoit $P$. falciparum pada eritrosit dilakukan dalam bentuk tight junction yang didahului oleh terbentuknya antigen membran apikal (PfAMA1) pada merozoit dan kompleks RON pada eritrosit. ${ }^{15}$ Setelah terbentuk tight junction di permulaan invasi, isi dari organel rhoptry akan dikeluarkan untuk menyusun membran vakuola parasitophorous pada saat merozoit didorong masuk ke dalam eritrosit oleh gerakan motorik aktomiosin. ${ }^{31}$ Pada $P$. falciparum, waktu yang dibutukan untuk proses invasi ini sekitar 30 detik. ${ }^{29}$ Setelah terjadi fase invasi aktif, fase berikutnya adalah echinocytosis. Fase ini ditandai oleh menyusutnya eritrosit hingga berwujud menyerupai bintang akibat dari masuknya ion $\mathrm{Ca}^{2+}$ ke dalam eritrosit. ${ }^{29,30}$ Fase ini berlangsung selama 5-10 menit dan diakhiri oleh kembalinya eritrosit ke bentuk normal (bikonkaf). ${ }^{30}$

Plasmodium falciparum reticulocyte binding-like homologous protein 5 (PfRH5) merupakan ligan terpendek dari semua ligan PfRHs (63 kDa pada PfRH5 dan 200-375 $\mathrm{kDa}$ pada PfRH yang lain) dan tidak memiliki transmembran. ${ }^{19,34}$ Ligan ini berikatan dengan protein permukaan eritrosit yaitu basigin (CD147, EMMPRIN). ${ }^{35-37}$ PfRH5 juga membentuk kompleks dengan P. falciparum PfRH5-interacting protein (PfRipr) dan dengan cystein-rich protective antigen (CyRPA) untuk membentuk tight junction pada saat invasi (Gambar 2). Namun peranan kompleks PfRH5/PfRipr/CyRPA ini masih belum diketahui secara pasti. ${ }^{15,19,35,38}$ Dalam

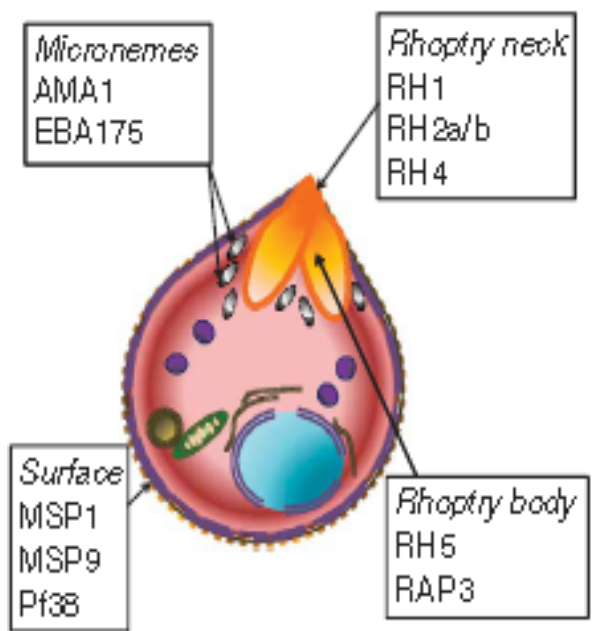

Gambar 1 Microneme dan Rhoptry Beserta Ligannya pada Merozoit ${ }^{16}$

Keterangan: Pada microneme dan bagian-bagian rhoptry terdapat sejumlah ligan yang digunakan untuk menginvasi serta memfasilitasi diversifikasi jalur bagi merozoit dalam menginvasi eritrosit untuk menghindari sistem imun hospes ${ }^{32,34}$

Sumber: Bustamante LY, Bartholdson SJ, Crosnier C, Campos MG, Wanaguru M, Nguon C, et al. A full-length recombinant Plasmodium falciparum PfRH5 protein induces inhibitory antibodies that are effective across common PfRH5 genetic variants. Vaccine. 2013;31(2):373-9. 


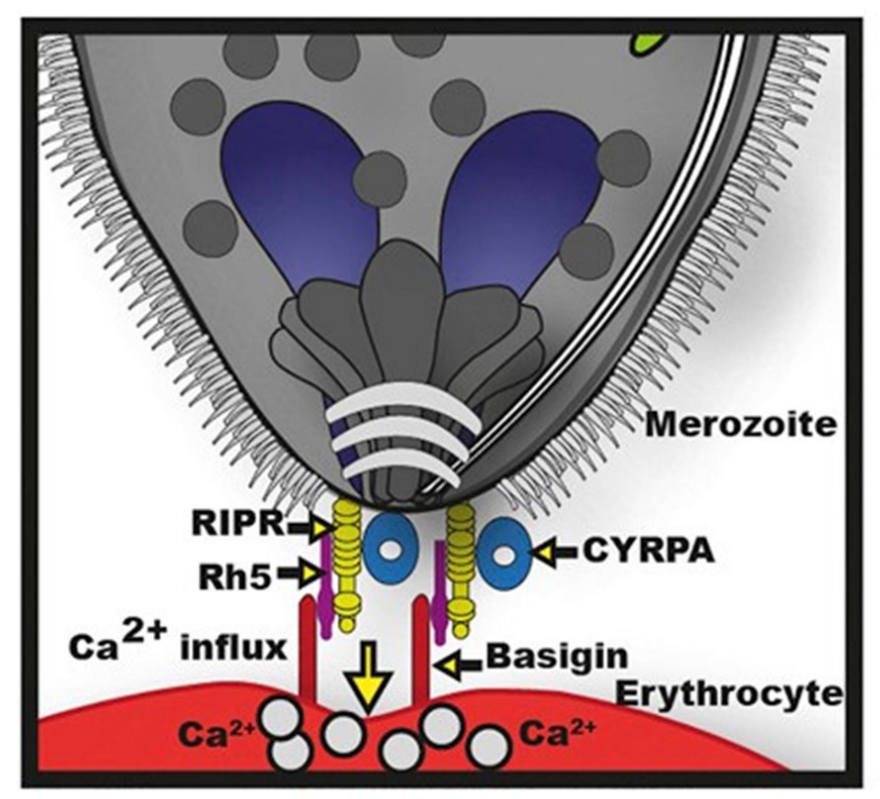

Gambar 2 Pengikatan Ligan PfRH5 pada Merozoit Terhadap Reseptor Basigin pada Eritrosit dalam Proses Invasi ${ }^{14}$

Keterangan: Pengikatan PfRH5 terhadap basigin berperan penting dalam proses invasi merozoit. Plasmodium falciparum menggunakan ligan PfRH5 dan membentuk kompleks dengan PfRipr dan CyRPA untuk memediasi invasi eritrosit dengan menempel pada reseptor basigin pada eritrosit ${ }^{19,35,36,38}$

Sumber: Volz JC, Yap A, Sisquella X, Thompson JK, Lim NT, Whitehead LW, et al. Essential role of the PfRh5/PfRipr/CyRPA complex during Plasmodium falciparum invasion of rythrocytes. Cell Host Microbe. 2016;20(1):60-71.

berbagai percobaan, PfRH5 merupakan satusatunya ligan yang tidak dapat dihilangkan di semua strain $P$. falciparum dan diduga protein PfRH5 diperlukan dalam viabilitas P. falciparum. ${ }^{5,34,37}$ Secara umum, PfRH5 diketahui hanya memiliki sebanyak lima nonsynonymous single nucleotide polymorphisms (SNPs). Hal ini menjadi bukti bahwa protein PfRH5 mempunyai sekuensi polimorfisme yang terbatas. ${ }^{17,39,40}$ Polimorfisme dari PfRH5 menentukan virulensi pathogen dan spesifisitas reaksi imun dari host $P$. falciparum. ${ }^{18}$

Penggunaan nanopartikel dalam pembuatan vaksin didasarkan pada pertimbangan dalam membuat vaksin yang efektif, menekan efek bahaya saat diaplikasikan, dan membuat agar tubuh pasien dapat menerima vaksin dengan baik. ${ }^{41}$ Liposom mempunyai karakteristik antara lain biokompatibilitas, mudah terurai karena terbentuk secara alami dari fosfolipid dan kolesterol, serta dapat mengontrol biodistribusi vaksin secara sistemik dengan mengubah ukuran, komposisi lipid, dan karakteristik fisiknya. Selain itu, nanopartikel liposom dapat melapisi substrat yang bersifat baik hidrofilik maupun hidrofobik dan dapat terus melepaskan substat yang terenkapsulasi, sehingga menjadi pembawa obat yang sangat efektif. ${ }^{42}$

Liposom dapat berfungsi sebagai sebuah pelindung terhadap degradasi biologis sebelum vaksin mencapai sel target sehingga dapat diaplikasikan sebagai sistem penghantaran dan pelindung vaksin. Sebagai penghantar vaksin, nanopartikel liposom dapat secara mudah dimodifikasi sesuai keperluan hingga menghasilkan penghantaran yang lebih spesifik. ${ }^{41}$ Liposom dirancang untuk menjadi multifungsi dengan komponen yang berbeda sehingga dapat memberikan kontrol atas sifat vaksin seperti permeabilitas, biodistribusi dan spesifisitas penargetan. Selain itu, enkapsulasi vaksin dengan liposom dapat meningkatkan farmakokinetik dan pelepasan 


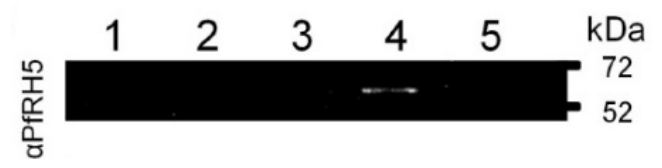

Gambar 3 PfRH5 pada Fraksi Liposom ${ }^{43}$

Keterangan: Hasil elektroforesis PfRH5 pada fraksi liposom

Sumber: Fotoran WL, Santangelo RM, Medeiros MM, Colhone M, Ciancaglini P, Barboza R, et al. Liposomes loaded with P. falciparum merozoite-derived protein are highly immunogenic and produce invasion-inhibiting and anti-toxin antibodies. J Control Release. 2015;217:121-7.

vaksin, memiliki kemampuan melakukan penetrasi seluler dengan mekanisme fusi membran liposom dengan plasma membran sel, kemampuan menuju target yang selektif, serta mencegah timbulnya inflamasi terhadap jaringan yang sehat. ${ }^{43}$

Pendekatan administrasi vaksin dengan liposom memiliki tujuan untuk menargetkan antigen yang ditentukan. ${ }^{21}$ Pada studi Fotoran et al. (2015), ${ }^{43}$ antigen PfMSP1 dan PfRH5 dapat secara efisien ditransfer ke liposom dan meningkatkan dispersitas partikel secara signifikan. Formulasi proteoliposome sangat imunogenik serta menghasilkan antibodi yang mengenali struktur asli dengan potensi menginhibisi invasi sehingga administrasi vaksin dapat menjadi lebih efektif (Gambar 3). Selain itu, preinkubasi dari parasit lysate dengan proteoliposome yang terinduksi antiserum secara signifikan dapat menurunkan sitokin pro-inflamasi dan marker makrofag sehingga menunjukkan efek samping antitoksik. $^{44}$

Vaksin dengan liposomal menyebabkan peningkatan stabilitas vaksin dalam sistem sirkulasi, mencegah degradasi oleh enzim dan berukuran nano sehingga dapat menghindar dari sistem removal oleh ginjal atau reticulo endothelial system (RES)., ${ }^{3,45}$ Perkembangan liposom untuk penghantaran vaksin memiliki beberapa hambatan seperti stabilitas selama penyimpanan, scaling up, dan strerilisasi. ${ }^{45}$ Hal ini perlu diteliti secara lebih lanjut untuk meningkatkan efektifitas dan keamanan dalam sintesis vaksin.
Vaksin sebagai upaya pencegahan penyakit merupakan salah satu objek penelitian intensif dalam penanganan malaria khususnya $P$. falciparum. Vaksin PfRH5 untuk P. falciparum malaria ditargetkan pada fase eritrositik dengan berdasarkan perjalanan penyakitnya. ${ }^{18}$ Reaksi imun dalam bentuk aktivitas antigenantibodi yang kompleks pada fase eritrositik dapat menimbulkan berbagai macam antigen yang bermunculan sebagai kandidat vaksin. Vaksin PfRH5 tersebut dinilai berdasarkan seberapa pentingnya peranan antigen dalam menimbulkan respon antibodi sehingga dapat menghasilkan respon imun protektif yang adekuat. ${ }^{20}$ Antigen dengan profil polimorfisme tinggi menyebabkan parasit malaria dapat menghindar dari sistem imun host. Polimorfisme tersebut menyebabkan perubahan sifat antigenik yang sewaktuwaktu dapat berakibat pada resistensi. ${ }^{24}$

Meski PfMSP dan PfAMA telah terbukti dapat menginduksi pembentukan antibodi penghambat pertumbuhan $P$. falciparum, akan tetapi masih belum terdapat penelitian yang menjelaskan secara spesifik terkait mekanisme inhibisinya. Sementara itu, antigen kelas PfRH telah ditemukan memiliki peran penting dalam proses invasi merozoit $P$. falciparum pada sel eritrosit, hal ini membuat antigen PfRH memiliki mekanisme kerja yang lebih spesifik dan dasar dalam patogenitas P. falciparum yang perlu dicegah., ${ }^{9,11}$ Terlebih lagi, PfRH5 memiliki sekuens polimorfisme yang terbatas dan kemampuan untuk menginduksi aktivitas antibodi inhibitor yang luas setelah dilakukan 


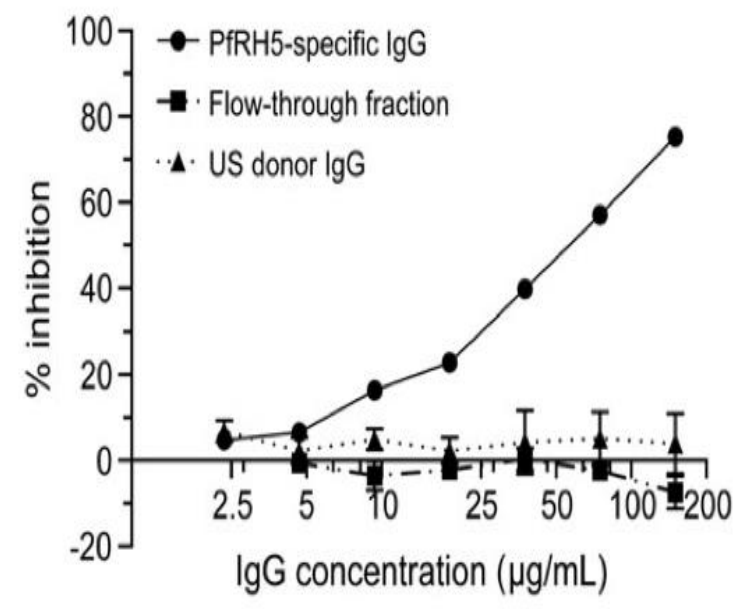

Gambar 4 Aktivitas Inhibisi dari IgG Terinduksi PfRH5 Terhadap Pertumbuhan Plasmodium falciparum Secara in vitro ${ }^{46}$

Keterangan: Aktivasi IgG terinduksi PfRH5 dalam proses inhibisi Plasmodium falciparum secara in vitro

Sumber: Douglas AD, Baldeviano GC, Lucas CM, Lugo-Roman LA, Crosnier C, Bartholdson SJ, et al. A PfRH5-based vaccine is efficacious against heterologous strain blood-stage Plasmodium falciparum infection in aotus monkeys. Cell Host Microbe. 2015;17(1):130-9.

vaksinasi pada hewan. ${ }^{13,23}$

Dengan profil polimorfisme antigen yang rendah, kemungkinan resistensi terhadap vaksin akan semakin kecil. Vaksin PfRH5 dengan pelapisan oleh nanopartikel liposom menyebabkan terjadi pertahanan signifikan terhadap vaksin agar dapat menginduksi antibodi secara maksimal, hal ini dibuktikan dalam penelitian Douglas et al. (2014). ${ }^{45}$ yang menyatakan bahwa imunisasi dengan virus rekombinan yang mengekspresikan PfRH5 menghasilkan antibodi terhadap beberapa strain $P$. falciparum. Hasil ini juga didukung dengan penelitian mengenai potensi full-length recombinant PfRH5 yang menunjukkan mekanisme induksi antibodi dengan daya inhibisi invasi yang kuat dan dapat menghambat pertumbuhan sembilan jenis strain $P$. falciparum. ${ }^{17}$

Potensi PfRH5 sebagai kandidat vaksin juga diperkuat dengan adanya respon antibodi alami yang dapat mencegah pertumbuhan parasit dan menunda terjadinya episode malaria. Hal ini dibuktikan melalui perbandingan antara IgG terinduksi PfRH5 dan IgG dari donor sehat dengan uji growth inhibition assays (GIAs). Hasil uji menunjukkan adanya konsentrasi minimal dibutuhkan untuk aktivitas inhibisi parasit $\left(\mathrm{Ab}_{50}=55 \mu \mathrm{g} / \mathrm{mL}\right)$ pada $\mathrm{IgG}$ terinduksi PfRH5, sementara tidak terdapat aktivitas inhibisi sama sekali dari IgG donor sehat (Gambar 4) ${ }^{46}$ Selebihnya, PfRH5 ditemukan dapat menginduksi respon antibodi $\mathrm{IgG}$ spesifik secara alami pada pasien malaria falciparum sejak awal fase eritrositik hingga timbulnya gejala malaria dalam durasi 71 hari. ${ }^{46}$ Hal ini menunjukkan bahwa dengan adanya antibodi spesifik dalam tubuh maka dapat meningkatkan sistem kekebalan tubuh terhadap $P$. falciparum malaria pada musim transmisi malaria atau bahkan menurunkan risiko terjangkit penyakit.

Meningkatnya sistem imun protektif terhadap P. falciparum melalui antigen PfRH5 juga didukung oleh penelitian dari Douglas et al. $(2014)^{45}$ yang telah membuat vaksin yang mengeskpresikan beberapa antigen siklus eritrositik yaitu PfMSP (PfMSP1, PfMSP9), PfAMA (PfAMA1), PfRAP (PfRAP3), dan PfRH (PfRH2 dan PfRH5). Hasil uji ELISA 


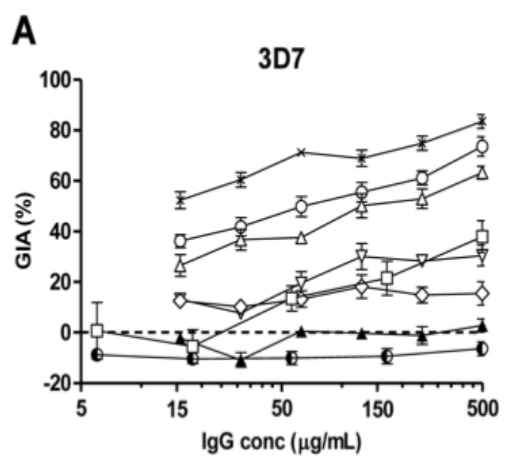

\section{Gambar 5 Efek Inhibisi dari Antibodi Monoklonal Anti-PfRH5 Terhadap Plasmodium falciparum pada GIA Assay $^{46}$}

Keterangan: Hubungan konsentrasi IgG terhadap hasil GIA pada strain 3D7 Plasmodium falciparum

Sumber: Douglas AD, Baldeviano GC, Lucas CM, Lugo-Roman LA, Crosnier C, Bartholdson SJ, et al. A PfRH5-based vaccine is efficacious against heterologous strain blood-stage Plasmodium falciparum infection in aotus monkeys. Cell Host Microbe. 2015;17(1):130-9.

menunjukkan antibodi titer melebihi 10.000 khususnya untuk PfRH2 dan PfRH5. Dari hasil penelitian tersebut, diperoleh pembentukan antibody IgG spesifik akan meningkat secara signifikan dengan adanya paparan terhadap antigen yang dilemahkan sebelumnya dan efek inhibisi akan lebih baik lagi. ${ }^{45}$

Studi mengenai mekanisme proteksi vaksin antibodi-anti PfRH5 saat ini baru sebatas secara in vitro. Beberapa studi menyatakan bahwa antibodi anti-PfRH5 memberikan proteksi terhadap sel host melalui ikatan antigen-antibodi yaitu mekanisme inhibisi terhadap interaksi PfRH5 dengan BSG dan melalui mekanisme netralisasi parasit oleh antibodi IgG spesifik. Pada patogenesis P. falciparum malaria, antigen PfRH5 berada pada permukaan merozoit, badan rhotropy skizon dan pada tahap awal invasi eritrosit sebelum terbentuknya tight junction antara parasit dengan eritrosit. ${ }^{46,47}$ Pada tahap awal invasi, adanya PfRH5 merupakan target potensial vaksin. Inhibisi antibodi PfRH5 terhadap penempelan PfRH5 pada BSG menyebabkan penurunan interaksi merozoit dengan eritrosit. ${ }^{47,48}$

Vaksin antibodi anti-PfRH5 juga dapat menetralisir merozoit. Mekanisme netralisasi dapat diukur secara in vitro dari kemampuan inhibisi antibodi terhadap antigen yang berperan dalam pertumbuhan parasit. Dalam uji dengan GI Assay tiga jenis antibodi monoklonal terhadap PfRH5 (QA1, QA5 dan 6BF10) yang terbentuk ditemukan dapat menghambat pertumbuhan parasit secara in vitro pada konsentrasi $500 \mu \mathrm{g} / \mathrm{mL}$ secara berturut-turut yakni sebesar 38\%, 63\% dan 30\% (Gambar 5). ${ }^{46}$ Selain itu, antibodi lainnya seperti 9AD4 dan 2AC7 memiliki afinitas yang rendah terhadap PfRH5, dapat menginduksi mekanisme netralisasi dengan potensi yang cukup tinggi dengan nilai EC50 (setengah dari konsentrasi efektif maksimal) yakni masing-masing sebesar $62 \mu \mathrm{g} / \mathrm{mL}$ dan $<15 \mu \mathrm{g} / \mathrm{mL} .{ }^{46} \mathrm{Hal}$ ini menunjukkan meskipun tanpa adanya ikatan yang baik, antibodi anti-PfRH5 masih memungkinkan untuk menetralisir merozoit sehingga menghambat pertumbuhan parasit pada uji in vitro. Hasil ini juga memungkinkan adanya mekanisme neutralisasi lain yang terjadi selain melalui inhibisi terhadap interaksi PfRH5 dengan BSG. Hal ini sesuai dengan pernyataan bahwa antibodi-anti BSG dapat menginduksi neutralisasi parasit dengan tanpa menghambat interaksi antigen-antibodi sehingga membuat 


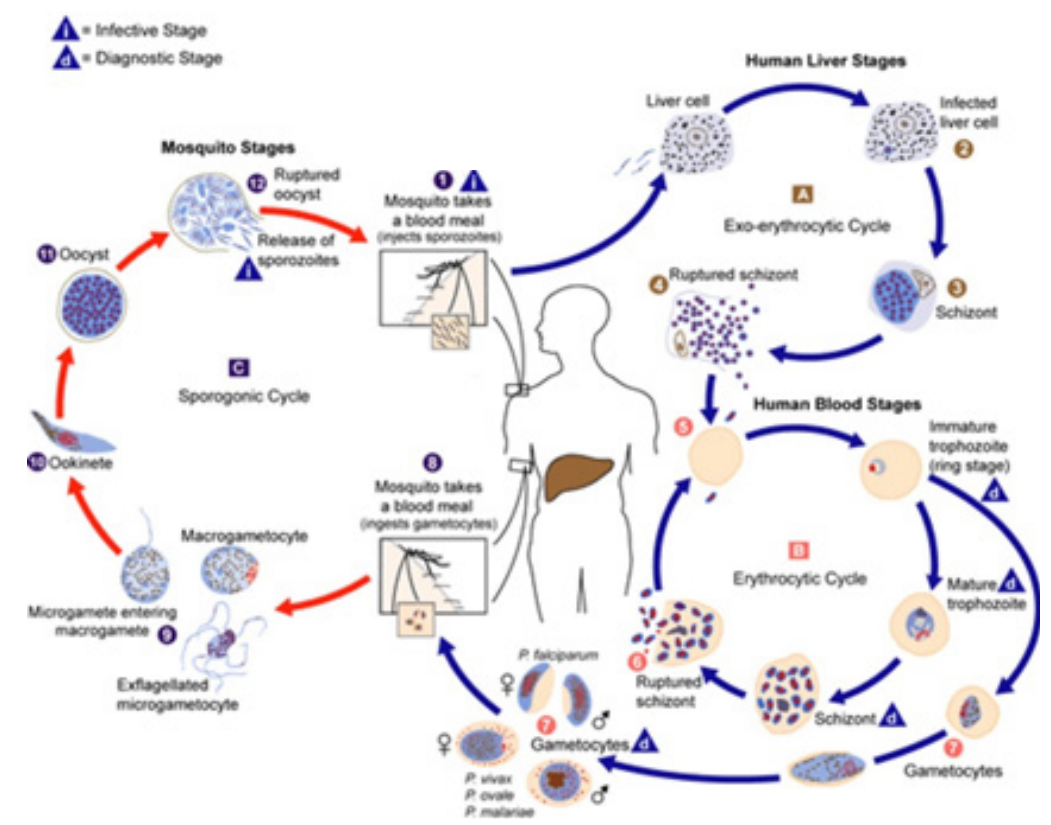

Gambar 6 Siklus Hidup Plasmodium falciparum ${ }^{24}$

Sumber: Weekley C, Smith DS. Malaria: The clinical basics. Global Health Education Consortium (GHEC); 2013.

peranan PfRH5 dalam menginduksi aktivitas imun protektif semakin luas. ${ }^{48}$

Vaksin merupakan penelitian yang sangat berkembang pesat karena potensinya yang besar dalam eradikasi morbiditas dan mortalitas penyakit. Apabila dibandingkan dengan upaya pencegahan transmisi malaria saat ini yang berkonsentrasi pada upaya pemberantasan vektor secara massal melalui tindakan sederhana, ${ }^{7}$ vaksin menawarkan terapi pencegahan dengan cara memberikan sebuah perlindungan yang dimulai dari dalam tubuh manusia itu sendiri. Sistem imunitas yang diinduksi juga dapat bertahan selama bertahun-tahun atau bahkan seumur hidup. ${ }^{31}$ Mengingat adanya prinsip herd community yang berarti semakin besar proporsi individu dalam masyarakat yang kebal terhadap penyakit infeksi, maka semakin kecil risiko bagi mereka yang tidak kebal di dalam populasi tersebut untuk terkena penyakit, ${ }^{31}$ dengan kata lain, proteksi secara tidak langsung diberikan oleh mereka yang sudah kebal terhadap mereka yang belum. Sesuai dengan pernyataan ini maka dengan bantuan vaksin malaria, sistem kekebalan tubuh manusia akan meningkat dan semakin kecil pula risiko akan terjangkitnya penyakit.

Vaksin malaria yang ideal merupakan vaksin dengan antigen yang memiliki spectrum yang luas terhadap strain $P$. falciparum dan memiliki peran penting untuk kelangsungan hidup parasit dan reproduksi, sehingga resistensi tidak dapat dengan mudah diperoleh dengan mutasi, atau dengan hanya mematikan ekspresi. ${ }^{15}$ PfRH5 merupakan antigen esensial dalam pathogenesis $P$. falciparum malaria, hal ini membuat PfRH5 menjadi target terapi mutakhir pada penatalaksanaan $P$. falciparum malaria.

Berdasarkan penelitian oleh Douglas et al. $(2015)^{46}$ didapatkan bahwa PfRH5FL memiliki potensi induksi antibodi yang lebih tinggi dibandingkan dengan antigen PfAMA1 dan PfMSP1. Selain itu, diketahui bahwa densitas dari polimorfisme pada PfRH5 lebih rendah 3,3 kali jika dibandingkan dengan 19 kDa C-terminus PfMSP1, sehingga PfRH5 memiliki kecenderungan mutasi yang lebih kecil. ${ }^{46}$ 
Kesuksesan dari suatu vaksin antigen dapat dipengaruhi oleh berbagai faktor yang terkait antigen yang terkandung di dalamnya, seperti imunogenisitas, spesifisitas, stabilitas, ketersediaan dan keamanan. ${ }^{42}$ Terkait dengan imunogenisitas, telah dibahas sebelumnya bahwa antigen PfRH5 mampu meningkatkan pembentukan antibodi. Berdasarkan hasil dari penelitian yang dilakukan Patel et al. (2013), ${ }^{3}$ antigen PfRH5 mampu dihasilkan secara stabil oleh bakteri E. coli dan memperlihatkan adanya reaksi imun terhadap serum pasien. Hal tersebut menunjukan adanya ketersediaan dan stabilitas dari antigen PfRH5. Protein PfRH5 pada merozoit memenuhi kriteria dalam spesifisitas, salah satunya disebabkan karena beberapa penelitian telah gagal untuk menguji penghapusan gen PfRH5, sehingga terbukti bahwa PfRH5 memiliki sebuah peran penting untuk viabilitas parasit. ${ }^{15}$ Selain itu, adanya spesifitas PfRH5 pada merozoit memungkinkan vaksin berbasis PfRH5 tidak akan mampu memengaruhi eritrosit atau bagian lain dari tubuh, sehingga kemungkinan besar tidak menginisiasi suatu respon autoimun. Hal tersebut juga menegaskan mengenai adanya peluang terbaik karena kekhususan yang dimiliki PfRH5 sehingga dikategorikan "aman" dan menjadi strategi efektif vaksin target. ${ }^{15,25,27}$

Selain itu, tingkat ekspresi dari PfRH5 tidak berubah pada strain $P$. falciparum dengan rute invasi yang berbeda. Hal ini telah dibuktikan dalam serum dari pasien yang menderita infeksi malaria alami ${ }^{34}$ yang menunjukkan bahwa PfRH5 adalah calon yang sangat baik untuk dimasukkan sebagai komponen dalam vaksin anti malaria yang sepenuhnya efektif. ${ }^{34}$ Kebutuhan merozoit untuk masuk dan bereplikasi dalam eritrosit memperlihatkan bahwa pengembangan vaksin merupakan hal yang paling masuk akal. Selain itu, karena manusia merupakan pembawa maupun penyebar kepada nyamuk, sangat penting untuk menemukan vaksin bagi manusia. Adapun vaksin dapat menghentikan penyebaran gametosit kepada nyamuk sehingga mampu mencegah pembentukan sporozoit dan reinfeksi manusia lainnya. ${ }^{35}$

Diperlukan penelitian lebih lanjut dengan tingkat yang lebih tinggi mengenai antigen PfRH5 untuk dapat mengetahui efektivitas dan keamanan vaksin pada tubuh manusia. Diharapkan dengan bukti ilmiah yang cukup, vaksin PfRH5 dapat digunakan dalam vaksin terhadap penyakit malaria.

\section{Simpulan}

Berbagai penelitian, baik penelitian in vitro maupun in vivo, yang telah dilakukan sampai saat ini menunjukkan antigen PfRH5 memiliki potensi yang besar sebagai vaksin P. falciparum malaria. Penggunaan antigen PfRH5 sebagai vaksin spesifik pada merozoit tidak akan memengaruhi eritrosit dan bagian tubuh lainnya. Rendahnya densitas polimorfisme pada PfRH5 menunjukkan rendahnya kecenderungan untuk mengalami mutasi yang berakibat pada resistensi. Selain itu, penggunaan nanopartikel liposom dalam distribusi dapat meningkatan bioavabilitas vaksin PfRH5. Dengan demikian, vaksin PfRH5 berbasis nanopartikel liposom dapat menjadi salah satu kandidat vaksin untuk penyakit $P$. falciparum malaria di masa depan. Perlu diingat bahwa penggunaan vaksin tidak mengganti upaya pencegahan konvensional mengingat prinsip keseimbangan antara host, lingkungan dan agen, sehingga upaya pencegahan harus dilakukan secara holistik.

\section{Pendanaan}

Penelitian ini tidak didanai oleh sumber hibah manapun.

\section{Konflik Kepentingan}

Seluruh penulis menyatakan tidak terdapat 
potensi konflik kepentingan dengan penelitian, kepenulisan (authorship), dan atau publikasi artikel ini.

\section{Daftar Pustaka}

1. World Health Organization. Guidelines for the treatment of malaria. $3^{\text {rd }}$ ed. Geneva: World Health Organization: 2014.

2. Gething PW, Patil AP, Smith DL, Guerra CA, Elyazar IR, Johnston GL, et al. A new world malaria map: Plasmodium falciparum endemicity in 2010. Malar J. 2011;10(1):378. doi: 10.1186/1475-2875 $-10-378$

3. Patel SD, Ahouidi AD, Bei AK, Dieye TN, Mboup S, Harrison SC, et al. Plasmodium falciparum merozoite surface antigen, PfRH5, elicits detectable levels of invasion-inhibiting antibodies in humans. 2013;208(10):1679-87. doi: 10.1093infdi s/jit385

4. Kementerian Kesehatan Republik Indonesia. Riset kesehatan dasar. Jakarta: Badan Penelitian dan Pengembangan Kementerian Kementrian Kesehatan Republik Indonesia; 2013.

5. Hayton K, Gaur D, Liu A, Takahashi J, Henschen B, Singh S, et al. Erythrocyte binding protein PfRH5 polymorphisms determine species-specific pathways of Plasmodium falciparum invasion. Cell Host Microbe. 2008;4(1):40-51. doi: 10. 1016/j.chom.2008.06.001

6. Murhandarwati EE, Fuad A, Sulistyawati, Wijayanti MA, Bia MB, Widartono BS, et al. Change of strategy is required for malaria elimination: A case study in Purworejo District, Central Java Province, Indonesia. Malar J. 2015;14(1):318. doi: 10.1186/s12936-015-0828-7

7. Petersen I, Eastman R, Lanzer M. Drugresistant malaria: Molecular mechanisms and implications for public health. FEBS Lett. 2011;585(11):1551-62. doi: 10.101 6/j.febslet.2011.04.042

8. Fairhurst RM, Dondorp AM. Artemisininresistant Plasmodium falciparum malaria. Microbiol Spectr. 2016;4(3):10.1128/mic robiolspec.EI10-0013-2016. doi: 10.1128 \%2Fmicrobiolspec.EI10-0013-2016

9. Gosling RD, Cairns ME, Chico RM, Chandramohan D. Intermittent preventive treatment against malaria: An update. Expert Rev Anti-infect Ther. 2010;8(5): 589-606. doi: 10.1586/eri.10.36

10. Zenonos ZA, Dummler SK, MüllerSienerth N, Chen J, Preiser PR, Rayner $\mathrm{JC}$, et al. Basigin is a druggable target for host-oriented antimalarial interventions. J Exp Med. 2015;212(8):1145-51. doi: 10.1084/jem.20150032

11. Draper SJ, Angov E, Horii T, Miller LH, Srinivasan P, Theisen M, et al. Recent advances in recombinant protein-based malaria vaccines. Vaccine. 2015;33(52): 7433-43. doi: 10.1016/j.vaccine.2015.09. 093

12. Agnandji ST, Lell B, Fernandes JF, Abossolo BP, Methogo BG, Kabwende AL, et al. A phase 3 trial of RTS, S/AS01 malaria vaccine in African infants. N Engl J Med. 2012;367(24):2284-95. doi: 10.10 56/NEJMoa1208394

13. Wright KE, Hjerrild KA, Bartlett J, Douglas AD, Jin J, Brown RE, et al. Structure of malaria invasion protein RH5 with erythrocyte basigin and blocking antibodies. Nature. 2014;515(7527):42730. doi: 10.1038/Fnature13715

14. Volz JC, Yap A, Sisquella X, Thompson JK, Lim NT, Whitehead LW, et al. Essential role of the PfRh5/PfRipr/CyRPA complex during Plasmodium falciparum invasion of rythrocytes. Cell Host Microbe. 2016;20(1):60-71. doi: 10.1016/j.chom.2 016.06.004

15. Richards JS, Arumugam TU, Reiling L, Healer J, Hodder AN, Fowkes FJ, et al. Identification and prioritization 
of merozoite antigens as targets of protective human immunity to Plasmodium falciparum malaria for vaccine and biomarker development. J Immunol. 2013; 191(2):795-809. doi: 10.4049/jimmunol.1 300778

16. Bustamante LY, Bartholdson SJ, Crosnier C, Campos MG, Wanaguru M, Nguon $\mathrm{C}$, et al. A full-length recombinant Plasmodium falciparum PfRH5 protein induces inhibitory antibodies that are effective across common PfRH5 genetic variants. Vaccine. 2013;31(2):373-9. doi: 10.1016/j.vaccine.2012.10.106

17. Ord RL, Caldeira JC, Rodriguez M, Noe A, Chackerian B, Peabody DS, et al. A malaria vaccine candidate based on an epitope of the Plasmodium falciparum RH5 protein. Malar J. 2014;13(1):1. doi: 10.1186/1475-2875-13-326.

18. Reddy KS, Amlabu E, Pandey AK, Mitra P, Chauhan VS, Gaur D. Multiprotein complex between the GPI-anchored CyRPA with PfRH5 and PfRipr is crucial for Plasmodium falciparum erythrocyte invasion. Proc Natl Acad Sci U S A. 2015; 112(4):1179-84. doi: 10.1073/pnas. 1415 466112

19. Powles L, Xiang SD, Selomulya C, Plebanski M. The use of synthetic carriers in malaria vaccine design. Vaccines. 2015;3(4):894-929. doi: 10.3390/vaccine s3040894

20. Salazar-González JA, Gonzalez-Ortega O, Rosales-Mendoza S. Gold nanoparticles and vaccine development. Expert review of vaccines. 2015;14(9):1197-211. doi: 10. 1586/14760584.2015.1064772

21. He H, Yuan D, Wu Y, Cao Y. Pharmacokinetics and pharmacodynamics modeling and simulation systems to support the development and regulation of liposomal drugs. Pharmaceutics. 2019; 11(3):110. doi: 10.3390/pharmaceutics11 030110
22. Sinka ME, Bangs MJ, Manguin S, RubioPalis Y, Chareonviriyaphap T, Coetzee M, et al. A global map of dominant malaria vectors. Parasites Vector. 2012;5(1):69. doi: 10.1186/1756-3305-5-69

23. Ippolito MM, Denny JE, Langelier C, Sears CL, Schmidt NW. Malaria and the microbiome: A systematic review. Clin Infect Dis. 2018;67(12):1831-9. doi: 10. 1093/cid/ciy374

24. Weekley C, Smith DS. Malaria: The clinical basics. Global Health Education Consortium (GHEC); 2013.

25. O'Sullivan JM, Preston RJ, O'Regan N, O'Donnell JS. Emerging roles for hemostatic dysfunction in malaria pathogenesis. Blood. 2016;127(19):22818. doi: 10.1182/bloo d-2015-11-636464

26. Goheen MM, Campino S, Cerami C. The role of the red blood cell in host defence against falciparum malaria: An expanding repertoire of evolutionary alterations. $\mathrm{Br}$ J Haematol. 2017;179(4):543-56. doi: 10. 1111/bjh.14886

27. Ito D, Takashima E, Yamasaki T, Hatano S, Hasegawa T, Miura K, et al. Antibodies against a Plasmodium falciparum RON12 inhibit merozoite invasion into erythrocytes. Parasitol Int. 2019; 68(1):8791. doi: 10.1016/j.parint.2018.10.006

28. Hviid L, Jensen AT. PfEMP1-A parasite protein family of key importance in Plasmodium falciparum malaria immunity and pathogenesis. Adv Parasitol 2015;88:51-84. doi: 10.1016/bs.apa r.201 5.02 .004

29. Weiss GE, Gilson PR, Taechalertpaisarn T, Tham WH, de Jong NW, Harvey $\mathrm{KL}$, et al. Revealing the sequence and resulting cellular morphology of receptorligand interactions during Plasmodium falciparum invasion of erythrocytes. PLoS Pathog. 2015;11(2):e1004670. doi: 10.13 71/journal.ppat.1004670

30. Riglar DT, Richard D, Wilson DW, Boyle 
MJ, Dekiwadia C, Turnbull L, et al. Super-resolution dissection of coordinated events during malaria parasite invasion of the human erythrocyte. Cell Host Microbe. 2011;9(1):9-20. doi: 10.1016/j.chom.201 0.12 .003

31. Tham WH, Healer J, Cowman AF. Erythrocyte and reticulocyte bindinglike proteins of Plasmodium falciparum. Trends Parasitol, 2012;28(1):23-30. doi: 10.1016/j.pt.2011.10.002

32. Beeson JG, Drew DR, Boyle MJ, Feng G, Fowkes FJ, Richards JS. Merozoite surface proteins in red blood cell invasion, immunity and vaccines against malaria. FEMS Microbiol Rev. 2016;40(3):343-72. doi: 10.1093/femsre/fuw001

33. Alaganan A, Singh P, Chitnis CE. Molecular mechanisms that mediate invasion and egress of malaria parasites from red blood cells. Curr Opin Hematol. 2017;24(3):208-14. doi: 10.1097/MOH.0 000000000000334

34. Chen L, Lopaticki S, RiglarDT, Dekiwadia C, Uboldi AD, Tham WH, et al. An EGFlike protein forms a complex with PfRh5 and is required for invasion of human erythrocytes by Plasmodium falciparum. PLoS Pathog. 2011; 7:e1002199. doi: 10. 1371/journal.ppat.1002199

35. Crosnier C, Bustamante LY, Bartholdson SJ, Bei AK, Theron M, Uchikawa M, et al. Basigin is a receptor essential for erythrocyte invasion by Plasmodium falciparum. Nature. 2011;480:534-37. doi: 10.1038/nature10606

36. Baum J, Chen L, Healer J, Lopaticki S, Boyle M, Triglia T, et al. Reticulocytebinding protein homologue 5-An essential adhesin involved in invasion of human erythrocytes by Plasmodium falciparum. Int J Parasitol. 2009;39(3):371-80. doi: 10. 1016/j.ijpara.2008.10.006

37. Dreyer AM, Matile H, Papastogiannidis P, Kamber J, Favuzza P, Voss TS, et al.
Passive immunoprotection of Plasmodium falciparum-infected mice designates the CyRPA as candidate malaria vaccine antigen. J Immonol. 2012;188(12):622537. doi: 10.4049/jimmunol.1103177

38. Manske M, Miotto O, Campino S, Auburn S, Almagro-Garcia J, Maslen G, et al. Analysis of Plasmodium falciparum diversity in natural infections by deep sequencing. Nature. 2012;487(7407):375 -9. doi: $10.1038 /$ nature 11174

39. Williams AR, Douglas AD, Miura K, Illingworth JJ, Choudhary P, Murungi LM, et al. Enhancing blockade of Plasmodium falciparum erythrocyte invasion: Assessing combinations of antibodies against PfRH5 and other merozoite antigens. PLoS pathogens. 2012;8(11):e1002991. doi: 10. 1371/journal.ppat.1002991

40. Martien R, Adhyatmika A, Irianto ID, Farida V, Sari DP. Perkembangan teknologi nanopartikel sebagai sistem penghantaran obat. Majalah Farmaseutik. 2012;8(1):133-44. doi: 10.22146/farmas eutik.v8i1.24067

41. Ramana LN, Sethuraman S, Ranga U, Krishnan UM. Development of a liposomal nanodelivery system for nevirapine. J Biomed Sci. 2010;17(1):57. doi: 10.1186/1423-0127-17-57

42. Cern A, Marcus D, Tropsha A, Barenholz Y, Goldblum A. New drug candidates for liposomal delivery identified by computer modeling of liposomes' remote loading and leakage. J Control Release. 2017;252:1827. doi: 10.1016/j.jconrel.2017.02.015

43. Fotoran WL, Santangelo RM, Medeiros MM, Colhone M, Ciancaglini P, Barboza R, et al. Liposomes loaded with $P$. falciparum merozoite-derived protein are highly immunogenic and produce invasioninhibiting and anti-toxin antibodies. J Control Release. 2015;217:121-7. doi: 10.1016/j.jconrel.2015.08.045

44. Douglas AD, Williams AR, Illingworth 
JJ, Kamuyu G, Biswas S, Goodman AL, et al. The blood-stage malaria antigen PfRH5 is susceptible to vaccine-inducible cross-strain neutralizing antibody. Nature communications. 2011;2:601. doi: 10.103 8/ncomms 1615

45. Douglas AD, Williams AR, Knuepfer E, Illingworth JJ, Furze JM, Crosnier C, et al. Neutralization of Plasmodium falciparum merozoites by antibodies against PfRH5. J Immunol. 2014;192(1):245-58. doi: 10. 4049/jimmunol.1302045

46. Douglas AD, Baldeviano GC, Lucas CM, Lugo-Roman LA, Crosnier C, Bartholdson SJ, et al. A PfRH5-based vaccine is efficacious against heterologous strain blood-stage Plasmodium falciparum infection in aotus monkeys. Cell Host
Microbe. 2015;17(1):130-9. doi: 10.1016/ j.chom.2014.11.017

47. Rodriguez M, Lustigman S, Montero E, Oksov Y, Lobo CA. PfRH5: A novel reticulocyte-binding family homolog of Plasmodium falciparum that binds to the erythrocyte, and an investigation of its receptor. PLoS ONE. 2008;3(10):e3300. doi: 10.1371/journal.pone.0003300

48. Tran TM, Ongoiba A, Coursen J, Crosnier C, Diouf A, Huang CY, et al. Naturally acquired antibodies specific for Plasmodium falciparum reticulocytebinding protein homologue 5 inhibit parasite growth and predict protection from malaria. J Infect Dis. 2013;209(5): 789-98. doi: 10.1093/infdis/jit553 